\title{
Desmond O'Grady in Love with Alexandria: Select Poems in Translation
}

\author{
BY \\ Maysa Abdel Aal Ibrahim Abdel Aal \\ Lecturer at the English Department, Faculty \\ of Arts, University of Tanta \\ DOI : $10.12816 / 0053004$ \\ مجلة الدراسات التربوية والانسانية ـ كلية التربية ـ جامعة دمنهور .

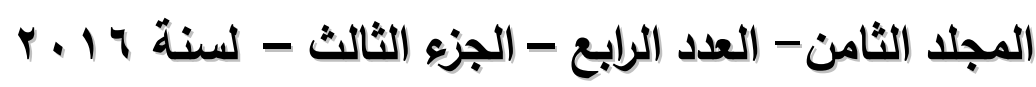




\title{
Desmond O'Grady in Love with Alexandria: Select Poems in Translation
}

\begin{abstract}
The challenging nature of the enterprise of translating poetry has not dismayed poets and translators from looking into other cultures and from venturing into the enterprise. Those who take a positive stance towards poetry translation are the ones who wish to explore, preserve, illuminate, and make known the cultures of other peoples. Among those is Desmond O'Grady, a contemporary Irish poet and translator, who translated poetry from different cultures and languages, including the Arabic Mu'allaqat, and who lived in different parts of the world, including Alexandria, Egypt.

O'Grady's poems are the subject of my translation in this paper. I have chosen to translate the poems he wrote for and about Alexandria, for their historical and emotional documentary value. I have endeavored to be as faithful to the original text as possible, while being faithful to the spirit and voice of the poet. I have also endeavored to create poems in the target language, which are enjoyable as independent, literary texts.
\end{abstract}




\section{Introduction}

Desmond O'Grady is a contemporary Irish poet and translator, born in Limerick, Ireland, in 1935 and died in 2014. As a child, he attended the Jesuit boarding school in Tipperary; then, in order to pursue his passion for art, he moved to Paris at the age of nineteen and there "he taught English at the Berlitz School and immersed himself in the artistic life of the city" (The Guardian, 1). In Paris, he met Picasso, befriended Ezra Pound, and moved in the artistic circles of Samuel Beckett and James Joyce. In 1956, he published his first book, Chords and Orchestrations, to be followed by many more. With a bent for discovery, O'Grady continued to move around from Paris to Rome, Harvard, Paros, Cairo, and Alexandria, before he finally settled in the late 1980's in Kinsale, Ireland, which he took as his hometown for the rest of his life. In all those cities, O'Grady was engaged in teaching and writing, and was dedicated to both vocations. While a Teaching Fellow at Harvard University, he took his M.A. and $\mathrm{PhD}$ there in Celtic languages and literatures and comparative studies. While in Rome, the Pope's spokesman and translator, O'Grady "became interested in translation and over the rest of his life he translated poetry from the Irish, Welsh, Arabic, Greek, Croatian, Turkish, and a variety of other languages" (The Guardian, 1).

Driven by a sharp keenness on knowing other peoples and other cultures, O'Grady led a life that was a journey of discovery and learning; Billy Mills depicts O'Grady's openness to other cultures in beautiful words:

Desmond O'Grady was unusual among Irish poets of his generation for both his interest in modernist

DOI : $10.12816 / 0052303$ 
experimentation and his immersion in the poetry of other cultures. He was, in the true sense, a citizen of world poetry, a fine translator, and a very fine poet (The Guardian, 1).

Mills quotes those lines from O'Grady's collection, Sing $\mathrm{Me}$ Creation, which I would also love to quote. In a poem entitled "Purpose" O’Grady says:"

I saw my life and I walked out to it as a seaman walks out alone at night from his house down to the port with his bundled belongings, and sails into the dark (O'Grady, 2).

Desmond O'Grady is a prolific writer and his poetry covers a wide range of topics, including love, people, places, and vocation. O'Grady has a unique voice among Irish, as well as worldwide poets, owing to his simple, yet tremendously idiosyncratic, use of language, a thing I consider an obstacle in the face of any translator of his work. O'Grady takes pride in being an Irishman and believes it is the Irish who taught the British the English language. As a consequence, he uses language in strange fashions, molds and shapes it in different ways so as to suit his own whimsical talents, allowing it to speak the unspeakable.

As an Irishman, O'Grady's sense of humor manifests itself overtly in his poetry. He manages to blend the serious with the light-hearted in a way that is almost unprecedented, making his work at once an enriching and enjoyable reading experience. His sense of humor is apparent in his descriptions of Alexandria. He endows her with female qualities and with profound human traits. At times he flirts with her, creating a man-woman love relationship between him and her. And at 
other times, his love for her wanes and she becomes a forsaken lover.

In the years 1978-1980, O'Grady was invited to be a full-time lecturer at the Department of English at the University of Alexandria, following a year he spent as Poet in Residence at the Department of English and Comparative Literature at the American University in Cairo. Inspired by Cavafy, E.M Forster, Lawrence Durrell, D.J Enright, and John Heath Stubbs before him, who all lived in Alexandria in different times and ways, O'Grady was intent on going there too and on getting first-hand experience of "that wily muse of the Mediterranean" (O'Grady, 3). He describes his feelings on his first trip from Cairo to Alexandria in ecstatic terms, "For this first visit my intention was to get a sense and a feel of what had been the city of Callimachus in classical and of Cavafy in modern times and it would be a new city on the Delta of a great river in my nomadic life from Ireland to Iran" (O'Grady, 3). And when Professor Karrara, chair-person of the English Department in Alexandria University offered him a two-year teaching contract, he felt that "living for two years in Alex would be a new experience and a natural extension of my Italian and Greek lives. I'd be at the navel of Western culture - in the Matrix of Southern Europe, the Eastern Mediterranean, Western Asia, And North Africa. It all looked four-square to me. Wallahi! Mabrouk" (O'Grady, 3). And when he arrived in Alexandria the following autumn, he thought, "My thoughts before sleep were that Alexandria might chart my last city in this life" (O'Grady, 3).

During the years O'Grady spent in Alexandria, teaching and writing, he lived a full life, much as any Egyptian citizen would do, immersed himself in the Alexandrian culture, mingled with its people, made friends, and left nothing he could possibly do undone. Owing to this and to his highly adaptive readiness, as well as to love of places and of

DOI : $10.12816 / 0052303$ 
exploring them, there arose a bond, as already mentioned, between O'Grady and Alexandria, one that reveals itself vehemently in his poems of Alexandria.

O'Grady's My Alexandria is an invaluable record of the city; it discloses an Alexandria portrayed from the point of view of a resident foreigner who is deeply in love with it, who overlooks all its negative aspects: the dirty streets, the shabby hotels, the poor people ..., etc. and who, with fond eyes, sees through to the essence of it. Owing to the fact that O'Grady, as already mentioned, was deeply immersed in the Alexandrian culture, the Alexandria he portrays is not one seen through the lens of a tourist, but it is one that any Alexandrian can identify with. O'Grady's poems are full of familiar Egyptian figures: a room-service Nubian boy, a street cobbler, a bar attendant, and, at the other end of the spectrum, Om Kalthoum, young Egyptian ladies..., etc. And in each picture he portrays, whether a place or a person, we do not feel the foreigner's critical eye, of Durrell's, for example, or even of Cavafy's; on the contrary, we feel the eye who sees beauty and meaning in every place and in every person.

It is for this reason, among others, that I have ventured into the enterprise of translating as vibrant and enigmatic a poet as Desmond O'Grady. The poems of Alexandria are invaluable, not only as a documentary record of the city, but also as an emotional one. O'Grady, in those poems, gives back Alexandrians their own home city seen with a fresh, romantic look that would revive it in their hearts forever.

But what with all the unresolved, on-going controversy over the translation of poetry; is poetry translatable? How much does poetry lose in its rendering to another language? How can one produce good poetry in the target language? Is it a worthwhile thing to do, after all? Those questions, among others, have been in the foreground over a long period of 
time. However, what has acted as a stimulant and driving force to this work was O'Grady's own views on translation. "Without translation," he said, "We would not know much about our neighbors" (O'Grady, 4). A strong proponent of translation, O'Grady wished for his poetry to be translated, as he has translated other poets himself.

Throughout my translation of O'Grady's poems, I have endeavored to be as faithful to the text as possible, meanwhile trying to render the light-hearted spirit of love prevalent in the poems. At times, I had to surmount difficulties, posed by an idiosyncratic language and style, by means of sacrificing faithfulness to the word for the sake of faithfulness to the overall meaning and spirit. To conclude, the journey of translating Desmond O'Grady's poems of Alexandria has been, for all the challenges faced, an enriching, as well as an enjoyable, one.

\section{ALEXANDRIA}

You, Alexandria, shine now my last city of all, last of the many I've waxed and wasted in, wandering. Some of us go through arrivals, lives, departures while others dread to move for downfall.

Witness of so much dazzle and destruction in wounding and curing time; yet still today sustainer of any prodigal with your achieved, apparently innocent serenity. I realize now you're the city I've journeyed to all the time. In you I begin again, not end, city of imagination.

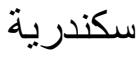

DOI : $10.12816 / 0052303$ 


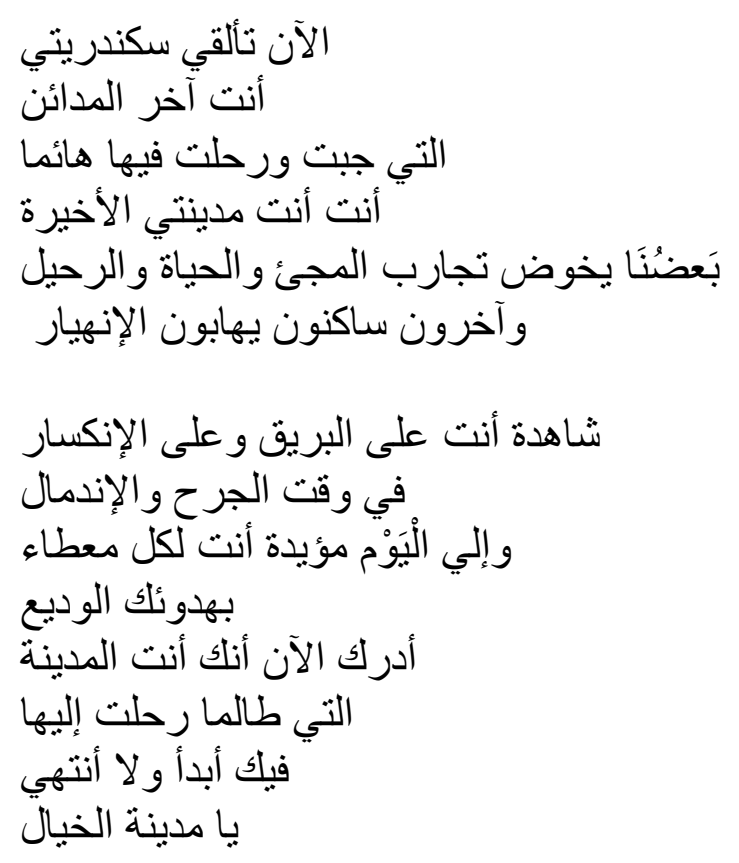

\section{HOTEL UNION}

Changed hotels

and I'm warming to my

bright-eyed Nubian servant boy

with his curly wire black hair, cherubic shiny face, Negroid nostrils, white teeth, that trustful smile shines glad-eyed, happy room-service. We pass frequently on my floor's corridor and I feel sure he prefers to bring me my tray and newspapers rather than let that greasy cook do it. I'm sure too he wants to; not because of all that professional paraphernalia in my room or because I'm always there, busy writing, studying in reclined repose. No.

When I pocket him baksheesh he always smiles 
his shy back-off as if there's more to his day than pawing local banknotes. That, I sense, he'd only accept with gutter disdain from others.

He's just brought my things from the laundry. There was concern in the way he laid every piece out, smoothing each with the pink palm of his sensuous black hand--as he oils my tired body. He mannequined my white suit before hanging it--to show, with glanced mirror smile splinters, these were clothes I, pasha, would wear tonight strolling, linked with a friend, along the Corniche. 
فندق يونيون

أنتقل إلى فندق آخر بون أشنعر بالألفة نحو خادمي الصبي النوبي ذو العينين اللامعتين والثعر الأسود كالسلك المجعد الوجه الملائكي المضئ والأنف الزنجي والأسنان البيضاء تشع إبتسامته السعيدة في عينيه الودودتين كما نشع خدمتة لي بالسعادة نتقابل كثبراً في أروقة الفندق يسعى في خدمتي، يأتي لي

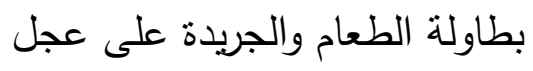

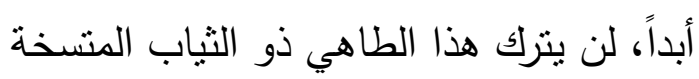

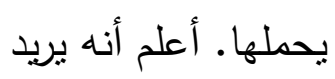
أن يقوم هو بخدمتي كاملة -

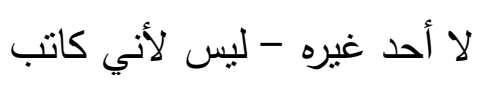
وغرفتي مليئة بسحرالقلم والأوراق المتناثرة في كل مكان أو لأني دائماً موجود بالغرفة، منشغل بكتابتي ومنغمس في قراءاتي في هدوء وسكون لا - ليس ذللك حيتسم إيتسامة تخفي خجلاً 


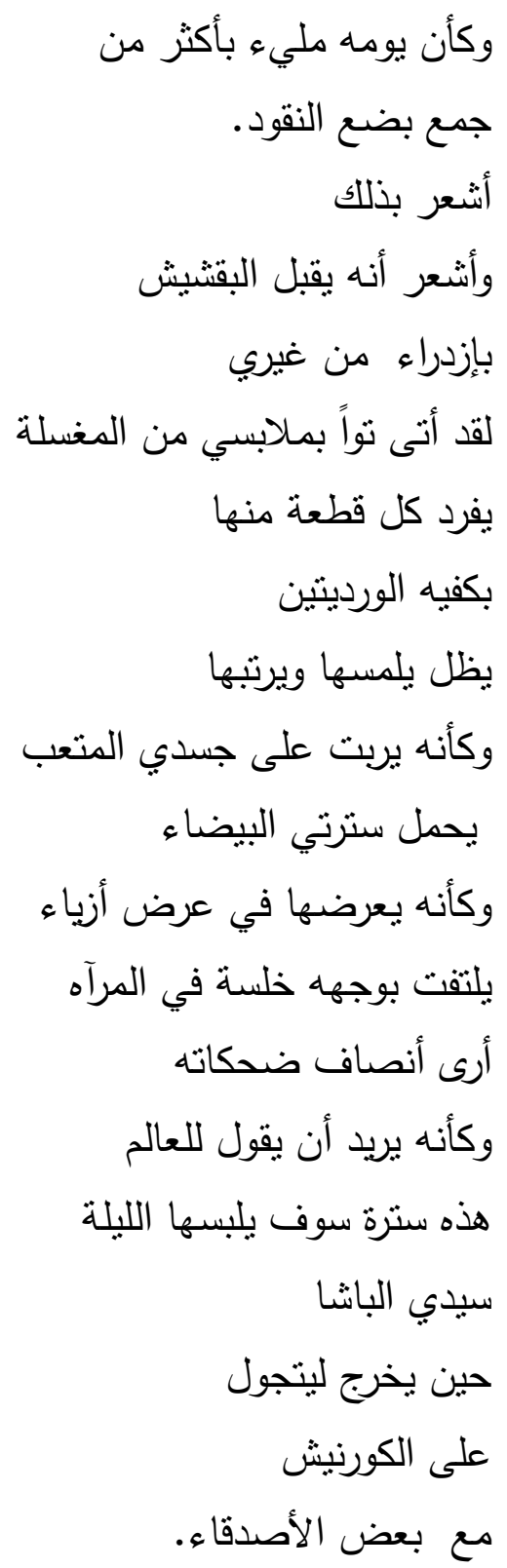




\section{UMM KALTHOUM}

'I sat at an old coffee table by Alexandria's Greek graveyard. My coffee lay black as charcoal thick as bog water. The landlord

waiter, Nubian, played his old scrape pickup. Umm Kalthoum sang out. Haunt of that held tone, long length high, then down

her scale. That steady voice lit as mosques, dark as love's mystery. Each poised note held, then drop

as the bowstring drops down the instrument sounds it. Voice of love, her religion, her people. Her way of it

miracles millions. From home her father's passed down tradition. She sang out The Book. The same sound style seannós came down

to my youth,' Ireland. Memories of old men, women in country kitchens intoned long night hours. Bend of that language beyond me. I copy them still at times humming alone in foreign places. Kalthoum's language sound seems 
natural soil of my native memories.

Lovers at night desert their beds

1 in the dark, slip silently out from

shut rooms, listen to the words

of Umm Kalthoum. I'm among them.

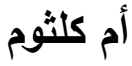

$$
\begin{aligned}
& \text { جلست على طاولة قهوة قديمة } \\
& \text { عند المقابر اليونانية بالأسكندرية } \\
& \text { قهوتي سادة سوداء منل الفحم } \\
& \text { مثنل مياه المستتقعات } \\
& \text { النادل النوبي يلعب لعبة } \\
& \text { التقاط الأوساخ. } \\
& \text { أم كلثوم تغني } \\
& \text { يتماوج صوتها حتى يصل } \\
& \text { إلى أعلى المقامات ثم يعود فينخفض لهض } \\
& \text { هذا الصوت الثابت يتلألأ } \\
& \text { منل صوت الآذان } \\
& \text { عميق منل غموض الحب } \\
& \text { كل نوتة موسيقية منزنة } \\
& \text { تثتبت } \\
& \text { ثم تسقط } \\
& \text { كما بسقط وتز الآلة الموسيقية } \\
& \text { ليحدث الصوت } \\
& \text { صوت الحب، دينها، قومها }
\end{aligned}
$$




$$
\text { طريقتها تدهش الملايين }
$$

إن تقاليد بيت والدها تتوارث

فهي ترنل القرآن

طراز صوتها القديم يعود بي نري

$$
\text { إلى شبابي في أيرلندا }
$$

وذكريات الرجال المسنين،

النساء ترتل في مطابخ الريف

ساعات طويلة من الليل.

فصاحة هذه اللغة تتعدى خيالي وأقلدهم أنا أحياناً أدندن وحدي لتهدي

في أماكن غريبة

صوت لغة أم كلثوم مرآه طبيعية

$$
\text { لذكرياتي في أيرلندا. }
$$

الأحبة يهجرون مضاجعهم في الليل الدامس

ويتحسسون طريقهم بهدوء

إلى خارج غرفهم المغلقة

ليستمعوا إلى كلمات أم كلثوم

بي 


\section{LACK}

I lack you at every silent sunset when we would never need talk between us. The place peopled yet

personless. I lack your impulsive movements' silences, your explosive smiles that see no shelter.

1 lack you in that tame elegance of your flung casual clothes' hang elegant on your striding aristocratic skeleton. Every movement synthesizes syncopation.

I'm daily devoid of the security of your presence, camaraderie, the challenge of all chance and cowardice, mine; unspoken assurance of all we could easily sweep together ... I'll always lack all we might have made. Must celebrate that through imagination. 


$$
\begin{aligned}
& \text { حنين } \\
& \text { أحن إليك في كل غروب هادئ } \\
& \text { حينما لا نحتاج الكلام } \\
& \text { المكان ملئ بالناس لاس } \\
& \text { ولكنه خالى بدونك } \\
& \text { أحن إلي سكون حركاتك المندفعة العفوية، } \\
& \text { إبتسامتك الساحرة } \\
& \text { التي لا يمكنك إخفائها. } \\
& \text { أحن إلي أناقتك في الثياب } \\
& \text { الهفهافة التي تتهادى علي التي } \\
& \text { قوامك الأرستقراطي. } \\
& \text { كل حركة من حركاتك تجعلني } \\
& \text { أغيب عن الوعي. }
\end{aligned}
$$

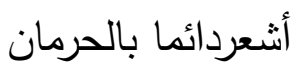

$$
\begin{aligned}
& \text { من الأمان الذي يضفيه } \\
& \text { وجودك، } \\
& \text { اشعر بالحرمان من صحبتلك } \\
& \text { في الحياة } \\
& \text { واعترف بعجزى امام التحديات } \\
& \text { والجبن الذي بعتريني }
\end{aligned}
$$

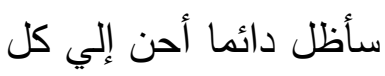

$$
\begin{aligned}
& \text { ما كان يمكن أن } \\
& \text { نستتتع به معاً. } \\
& \text { لابد أن أحيي هذا في الخيال. }
\end{aligned}
$$




\section{ALEXANDRIA ELEGY}

Your glance last night took me back to our while together on that bed we call our Mediterranean.

You have seen so much worth and dross wash up to your door with each slow change on the seas of time.

When this sailor shipped in to you, searching for all might give him safe anchorage on life's voyage,

he took you as he found you: bypassed but still lovely, tied to no one but your glorious past.

Languor in an older, well-bred woman challenges her chosen man to shape a life for both.

She may inspire some new play from each day's tired script will cast those parts gone dull in live, fresh roles.

Of noble lineage, to me you played that part and locked it in your deceptive shades of

autumn, darks of winter when we burned late night candles in hideouts of imagination's fantasy.

Then you took my every vocal entrance or silent exit with feigned interest, in comic or tragic pose.

Sweet spring. Then summer's white light brought distracting fashions with large sunhats that hid your ages-old features. 
With time those seasons' comedy lose their strained free laughter

So's not to end in tragedy's betrayal.

That's when it's time to pack and move life's show elsewhere. I did just that and left with one slow wave. 


\section{رثاء للأسكندرية}

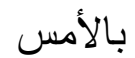

$$
\begin{aligned}
& \text { أخذتني نظر اتك } \\
& \text { إلى زمان كنا فيه معاً } \\
& \text { أخذنتي إلى فر اشيّ عشنا فئا فيه معاً } \\
& \text { ذللك الفر اش الذي سميناه } \\
& \text { البحر الأبيض المتوسط الأيطاه } \\
& \text { لقد ارتطم على شطآنك الكثير } \\
& \text { من الجميل و القبيح } \\
& \text { وشاهدت أنت ذلك الك } \\
& \text { مع كل هزة أتتلك على بحر الزئ الزمن } \\
& \text { حين ابحر إليك هذا البحار }
\end{aligned}
$$

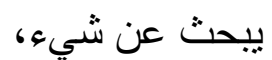

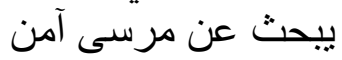

$$
\begin{aligned}
& \text { يأويه في رحلة الحياة ... } \\
& \text { أحبلكِ كما أنت } \\
& \text { رآك قد تجاوز كمانك الزمن }
\end{aligned}
$$

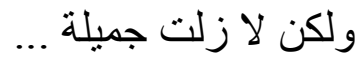

$$
\begin{aligned}
& \text { رآلك لا تنحني إلى غيرك جيل } \\
& \text { و الا لا تكترثي } \\
& \text { إلا بمجدك وتاريخك العظيم } \\
& \text { كنت لي أثنبه بزوجة } \\
& \text { تجاوزت الستين، } \\
& \text { ولكن من أصل طيب، } \\
& \text { تحث زوجها على مو اجهة التحديات } \\
& \text { فكان على أن أبحث } \\
& \text { عن شكل لحياة نعيشها معان أنسا } \\
& \text { وكنت الزوجة التي تغزل } \\
& \text { الحكايات و المسرحيات }
\end{aligned}
$$


من نصوص صو مبة معتادة

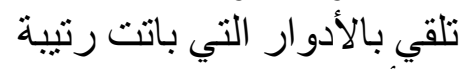

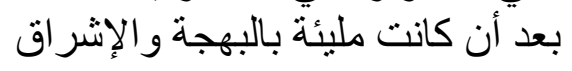

$$
\begin{aligned}
& \text { كنت تلعبي هذا الدور لي } \\
& \text { تكنينه في ظلال خريف تلكي } \\
& \text { في ظلمات الثتاء } \\
& \text { حين نطفئ الثموع فئ الثناء } \\
& \text { في مخابئ الخيال } \\
& \text { ثم بعد ذلك أخذت أنت } \\
& \text { كل دخول وخروج لي } \\
& \text { صامتا كان أم منطوقات } \\
& \text { بشيء من الإهنمام المصطنع أمنام } \\
& \text { وجاء الربيع الجميل } \\
& \text { وتلاه الصيف بنوره المضيء الجميء }
\end{aligned}
$$

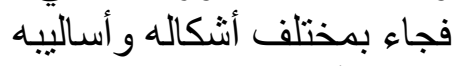

$$
\begin{aligned}
& \text { فلبست أنتِ القبعات الكبيرة }
\end{aligned}
$$

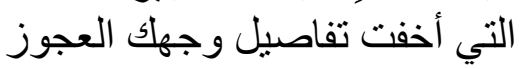

$$
\begin{aligned}
& \text { ومع الوقت أصبح تغيرك مع الفصول } \\
& \text { هزل لا فائدة منه اله اصن } \\
& \text { فصار حتى لا يضحك ضحكاً مفتعلاً }
\end{aligned}
$$

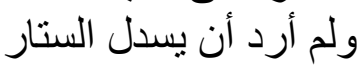

$$
\begin{aligned}
& \text { على مشهد الخيانة } \\
& \text { فاخترت أن يكون هذا وقت الرحيل } \\
& \text { وقت حزم الأمتعة ت ونكة } \\
& \text { ونقل مسرح الحياة } \\
& \text { إلى مكان آخر } \\
& \text { ففعلت ذلك مان اخت }
\end{aligned}
$$

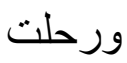

$$
\begin{aligned}
& \text { وودعنلك في هدوء. }
\end{aligned}
$$




\section{FELLAHIN IN TOWN}

I gaze through the sea-facing window of the Cecil Hotel lounge bar:-

Pharos portside, Cleopatra starboard. Unexpectedly

motorcycle police outside escorting the open limousine of visitor Presidents Sadat and Carter waving hello and goodbye as they pass

towards the Arab Quarter and that American aircraft carrier at anchor off Alexandria's naval harbour. Shades of eighteen eighty-two.

Gone, young local Egyptians round me talk excitedly of the prospects

for peace, of an end to military service new exit visas: future freedom.

They invite me home to share a meal. From the Delta, these fellows

say they want out to America, the English speaking world, a future.

I want in to their old world, that pre-Islamic time influenced Europe's

Middle Ages, Renaissance, Romance; into their troubadour culture.

They watch me observe the rooftops of those who live below them

on flat-roof farms of pigeon lofts, chicken coops and, in alleys,

goats, lamb, women, children boxed in by high-rise cement blocks.

'Fellahin' my hosts apologize. 'They're free' I offer. They agree, to please- 
a generation from fellahin themselves. We eat their peasant fare,

talk of work, life abroad: New York, London, Paris, Rome, Athens, Tokyo.

I try to explain western discriminations, in vain. Our meal over, I thank

their hospitality, walk back to my room, write this in their memory. 


\section{الفلاحين في المدينة}

وققت أحدق من نافذة بار فندق سيسل المطلة علي البحر

ميناء الفر اعنة وميمنة كليوبتر البحر

وفجأة تمر الدراجة البخارية

تصطحب الليموزين المفتوح الرئيس السادات و الرئيس كارنز يلوحون بأيديهم و هم يمرون تجادئ الرئي الحى العربى بائر وحاملة الطائر ات في مرسي ميناء الأسكندرية البحري

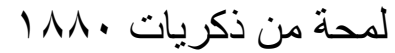
وبعد مرور السادات بدأ شباب المصريين حولي

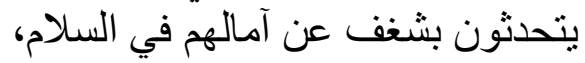
نهاية الخدمة العسكرية، فيز ات الخروج الجديدة ومستقبل حر

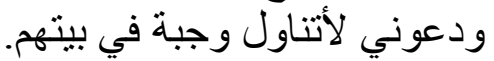
ومن الدلتا يتوق هؤلاء الثباب

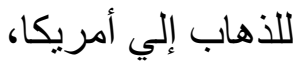
العالم المتحدث بالإنجليزية

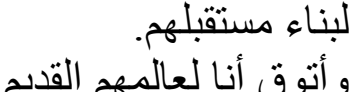
ماقبل الإسلام و أثره النيا في عصور أوروبا الوسطي، الأني، عصر النهضة، عصر الثناعرية، وخاصة إلي ثقافة شعر هم الغنائي. لقد وقفو اير اقبونني و أنا أنثاهد الغناني أسقف البيوت الأدني منهم المليئة بأبر اج الحمام و أكثاك الدون اجن 
و الماعز و الخرفان و النساء و الأطفال في الحواري مكدسين داخل كتل إسمنتية عالية. و أعنذر مستضيفيني قائلين: "إنهم فلاحين"

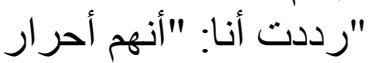

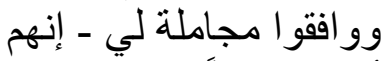
أنفسهر جيلاً من الفلاحين. وتتاولنا وليمتهم وتحدثنا عن الفالين العمل و الحياة في الخارج: نيويورك، لندن، باريس، رومان الئا، أثنينا، طوكيو. حاولت أن أوضح التفرقة العنصرية في الغرب ألغولي ولكن دون جدوي. بعد إنتهاء تناول الطعامي، شكرتهم علي حسن الضيافة و وعدت إلي حجرتي لأكتب هذه الذكريات. 


\section{CAVAFY IN ALEXANDRIA}

He's hidden everywhere here; not as he looks in his photographs but in his psyche, habits: his stylized diffidence, conservative decadence. I glimpse, detect him frequently: at night walking quickly down an alley close to the wall's shadow; afternoon in a tearoom alone glancing over the edge of his foreign newspaper, his eyeglasses; mornings at his desk in the crowded clerical bureaucracy where I must go to regularize my papers. He shows up behind one face or another in any of his private poems; they're in his glances. I may, one afternoon or evening, be introduced, (perhaps approached by him for staring) he sitting on the edge of a canapé, stiff in his correct, if shabby suit and tie, turned-in toes peering through spectacles out of his other-world expectancy. I feel nervous about what to say then, what to talk about. Yes? 


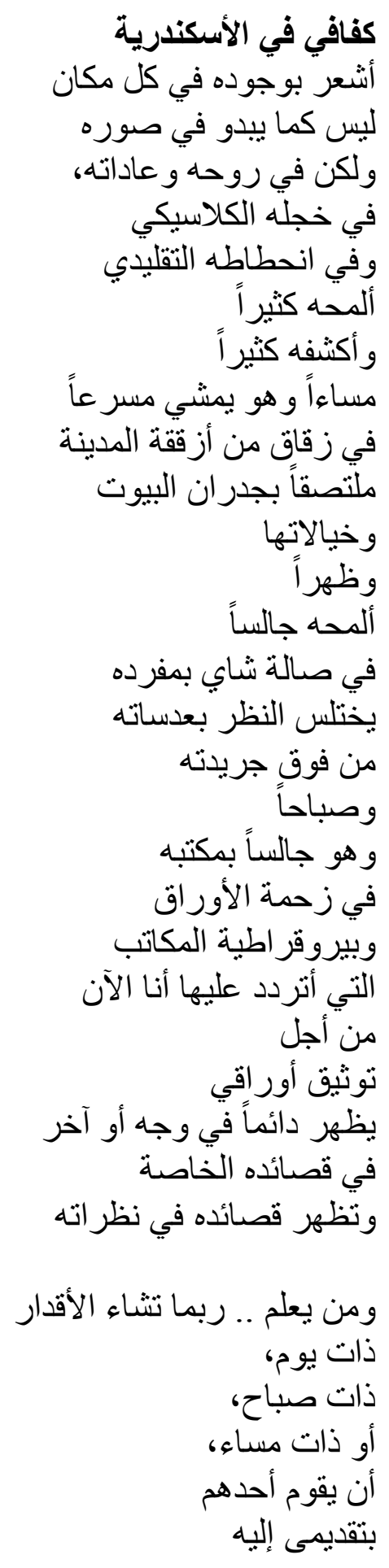




$$
\begin{aligned}
& \text { أو أنه يشعر بتحديقي فيه }
\end{aligned}
$$

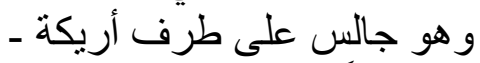

$$
\begin{aligned}
& \text { كلاسيكياً في سترته } \\
& \text { وربطه عنقه } \\
& \text { رغم قدمهح - رعنه } \\
& \text { يحدق } \\
& \text { من خلال عدساته } \\
& \text { من خلال عالمه الخاص، }
\end{aligned}
$$

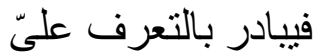

$$
\begin{aligned}
& \text { أشتعر بالتوتر لهذا اللقاء } \\
& \text { ماذا سأقول له؟ } \\
& \text { ماذا سأتحدث عناءث؟ } \\
& \text { أمحق أنا ؟ ماذأح }
\end{aligned}
$$




\section{THE BEACH AT MONTAZAH}

Back from my lone, barefoot paddle along the shore I lounge in the shade under dusty palms and pines. Muffled murmurs of the others' talk shift shadows behind me. You might well repose here with us too throating your assonantal Arabic, reading or poking for small shells with your toes along this sea's laced edge. But you repose elsewhere, with your cheekbones, Marchstone eyes, amber-in-sunlight flesh, glad smile.

For all this laid-back beach life, I hide my aloneness behind these protective scribbles and dream us both here alone or anywhere together talking, reading, paddling or preparing lunch for ourselves without need of casual converse--happy to share all that falls silently together. And yet, we have not yet begun. Not enough to dream, I desire your physical presence. But what if the dream is true, the truth nightmare? 


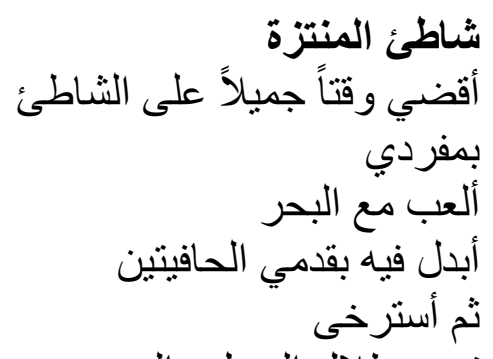

تحت ظلال النخيل و الصنوبر همسات الآخرين تبدل الظلآل

$$
\text { من ورائي }
$$

$$
\text { أريدك هنا معنا }
$$

تسترخى على الرمال تحدثيني بلسانك الموسيقي عئي تقر أبي كتناباً أو تدأعبي الرمال بأصابع قدميك

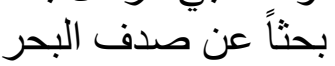
على حافة الأمو اج المزركثة الئة كالدانتلا

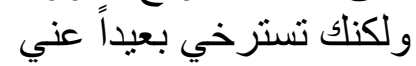
بوجهك النحيف ووجنتيك المنحونتين و عينيك الخضر اوتين مثل العقيق

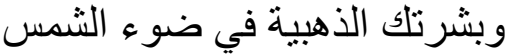
و إبتسامتلك الجميلة. رغم هذه الحياة الهادئة علي الثاطيء أخفي شعوري بالوحدة اتواري ور اءي هذه السطور الغامضة

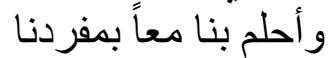
هنا أو هناك، أحلم بنا منا بمفيا نتحدث، نقر أ، نبدل في المياة النم

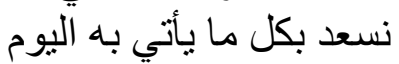
من سكينة و هدوء ولكن ... نحن لم نبدأ بعد 
لم نبدأ أن نحلم بعد أريدك،

أريد وجودك إكبو، إلى جانبي ولكن ....

ماذا لو تحول الحلم إلى حقيقة؟

ماذا لو تحول الحلم إلى كابوساً حقيقياً 


\section{THE CAPRI HOTEL}

Ashore, I take the cheapest room around at the Capri. Top floor. No elevator, no light. Dingy. One no-bulb no-flush lavatory down that closed-door corridor. This sort of room he must have used for shifty adventures here, long before different I shall.

Arabic music from the jugular alley below. Sibilant the sea, Greek blue her neckerchief since sunset. Floodlit Montazah Palace starboard west. Behind me, that desert we shale against ruin here. How many flea beds, shuttered alleyways; how many rivers, seas for solace? This charts my last city. I must make it my atavistic own for survival. After today's Clambake heat, a brisk breeze curls off the sea's mulled surface. Now's the hour to descend to those alleys of all manner human offal, find my removed café corner among those aged ghosts, consider the power of their pasts in my present. 


\section{فندق كابري}

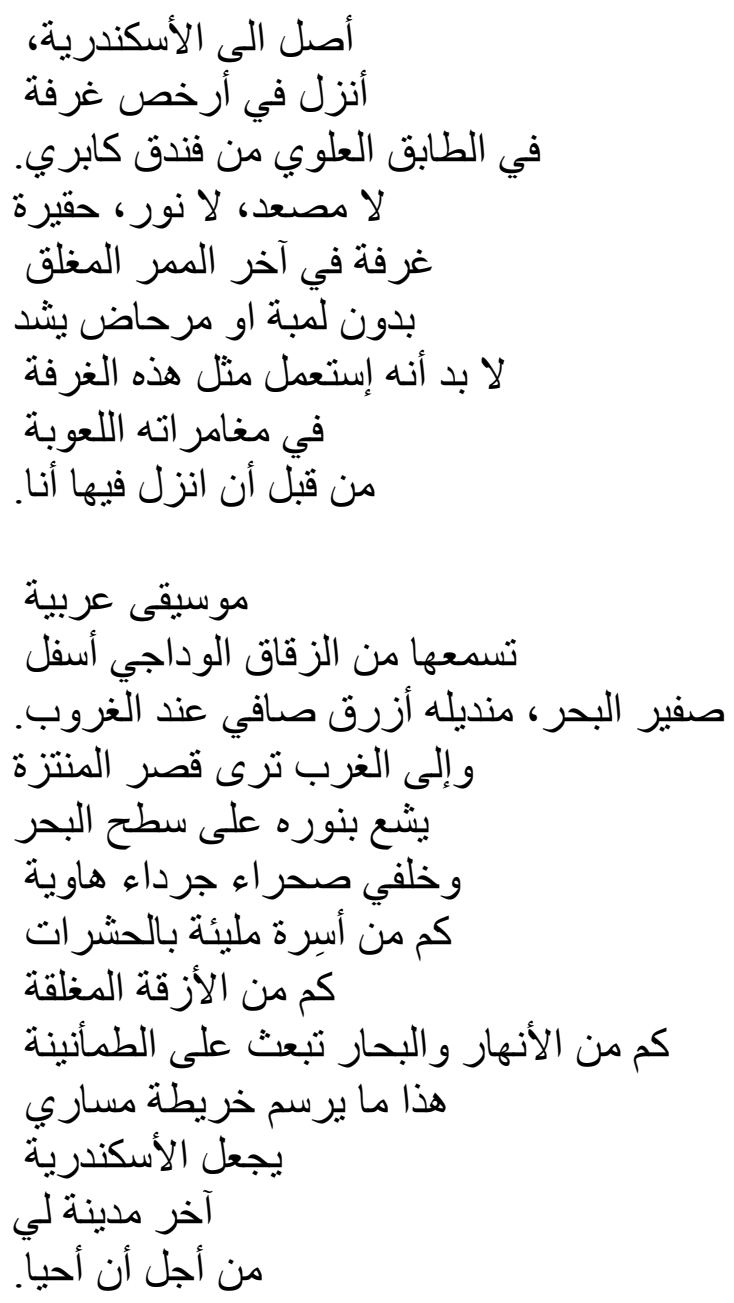

بعد شمس اليوم الحارقة تتهادى نسمة انتعاش الثمار التهر

على سطح البحر الساخن.

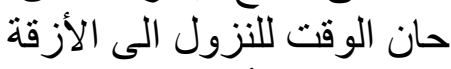
حيث الأخلاق الوضيعة الألية

لأجد ركني في المقهى الخاص بلي الاصيعة 


$$
\text { بين الاشباح العتيقة }
$$

أتخيل قوة ماضيهم في حاضري. 


\section{PASTROUDIS REVISITED}

After my long absence, thirteen years, I return unannounced, that long older. My first call's at Pastroudis to look for those friends used, at midday, on high chairs, sit to the bar for our aperitif.

We kept our bills in one glass on the shelf.

I find Pastroudis and its people changed.

The bar's gone. Gutted. My friends too gone elsewhere or dead. I stand awry on my own in a coffee-and-cake place, confused, estranged.

The customers today sit pairs in love and retired couples who don't speak or move. Then there, asquat, on the kerb, I recognize that form and face. He's shining shoes. Moustaches! He's dressed the same: flop hat, winter galoshes. He's seen and knows me too I realize and when our eyes meet he salaams a hand to head, slight-smiles sadly, shrugs the end.

I take a chair to him and place my foot on his old box. He takes my new shoes off, places his pavement mat. That's not enough. He proffers a cigarette from under his hat out of his ear. His spine's bent. His hair's grey, his teeth amber. One dead eye stares.

Neither of us comments on our lives or change. Silence speaks its own soliloquies. He's welcomed me as one from the old days who left for work elsewhere but now sits here 
again. My new shoes shone, he tips his moustache. I reach to pay. He whispers one word: Maalesh. 


\section{بسترودس من جديا}

بعد غياب طويل

بعد غياب ثناث عثر عاب طويل

أعود

أعود بلا مقدمات

أعود وقد تقدم بي العمر بلات مقر

تللك السنوات

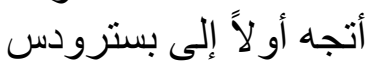

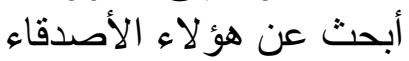

الذين عهدت أن أجلس معهم الاصداء

في الظهيرة

على كرأسي عالية

لنتناول الكحوليات

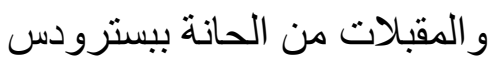

كنا نجمع الفو اتير في كوب والحن واتد

ولكن ...

أجد بسترودس و أناسه قد تغيروا

الحانة ذهبت

أصدقائي ذهبوا

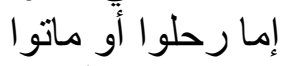

أقف وحدي في دهثة من أمري

في مجرد كافيه يقدم الثاى و الكيك أثي

أنثعر بالحيرة

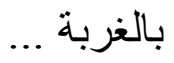

الزبائن اليوم يجلسون

كل زوجين على حدة الئى

أحبة - كاة

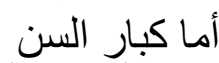

فيجلسون أيضاً أزو اجاً

في حالة صمت وسكون. 


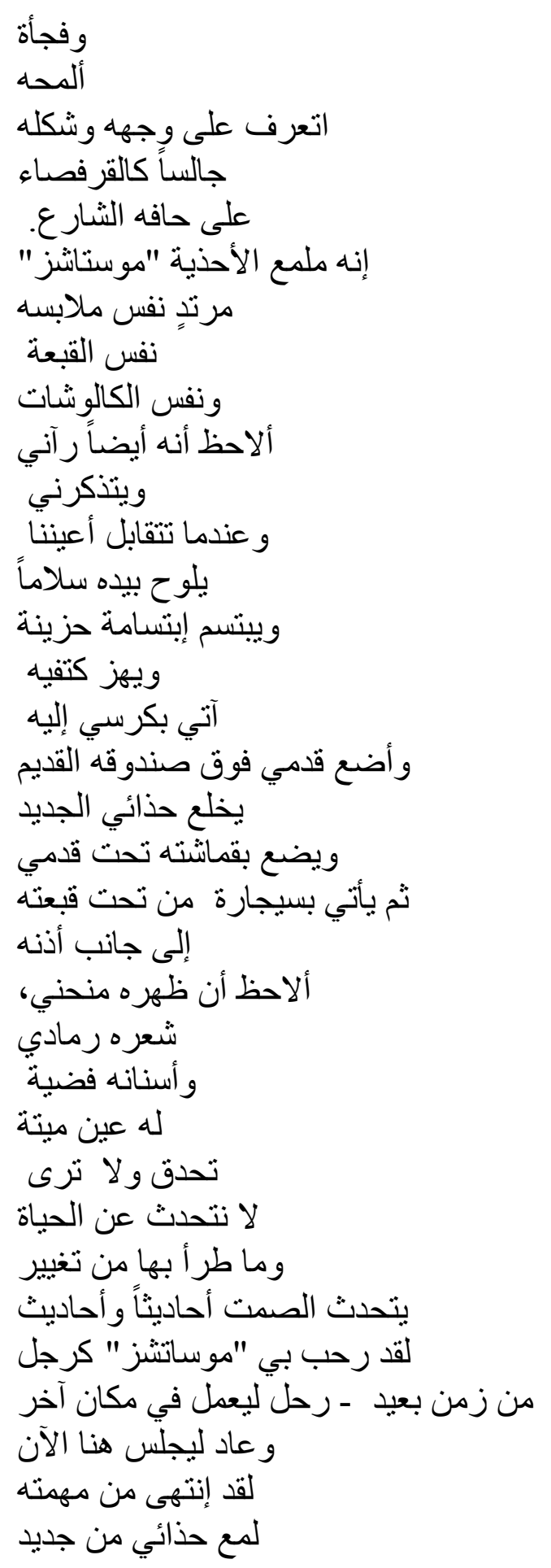


وبدأ بعبث بشاربه

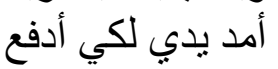

يهمس كلمة واحدة: "معلشي" لفع ليدي 


\section{COCKROACH}

I watch those dumbdumb cockroaches beetle directions along the cracks in my floorboards as these words do along the lines of my foolscap. Words appear like that. They crawl up in our half-dark from sewers of memory or down rusty pipedreams of tired imagination when we're alone at it. Then I observe them, eyebrow-detached, dispassionately crush them on the floor of my page without a bloody qualm. Tired of it, I switch off my light on them, descend to sleep. In the morning I'll mop up the blots before I stroll into sunlight and that crawling square. There I'll confront the hard glare of the lack of you. I'll sluggishly crawl the tramlines with those others who crush into that boxcar tram with we who beetle our dumbdumb directions to work in this stewhouse daily. 


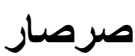

جلست أر اقب الصر اصير الغبية

تتهادي كالخنفساء

تتجه إلى الثقوق في أرض هذهرتي كادنياء

كما تزحف هذ فئ الكلمات

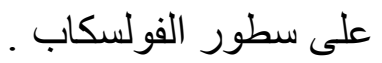

تتو الى الكلمات المبكات

تزحف في الجزء المظلم المات

من أعماق الذاكرة أو من الأحلام الصدأة

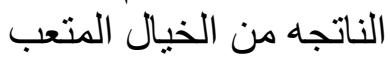

ونحن فى خلوة معها

ثم أر اقبهم بدهنة فئة فئقة

متجرداً من أي إحساس إنساس

ساحقاً إياهم

على أرض صفحتي بدون

أب وخز من ضمنير

حين أمل ذلك" أطفئ عليهم النور

و أخلا إلى النوم النور

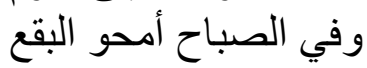

قبل أن أتهادي على ضوء الهي النهار

متجها إلى هذا الميدان الز الزف التف

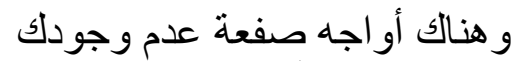

ثم أزحف خاملاً على قضبان الته الترام

مع هؤلاء الآخرين

الذين يُدهسون في عربة التر ام معنا لآحرين

فى هذا الصندوق المكنس بالأجساد البشرية البراية

من أجل الذهاب الى أعمالنا 


\section{ALEXANDRIAN SPRING}

Here, my manic winter has tired out its off-season. emptiness and although we do not have spring in our European sense of that experience, we have entered that interseasonal hiatus before we moult into our white effigy of summer. So these evenings, on my balcony with an aperitif, the sun setting beyond the Pharos, those migrant birds maneuver the breeze from the sea, prepare to fly north. I'm inwardly calm as a ship in a bottle sailing nowhere.

Down in the Cloister of our Convent I watch a nun in blue habit, white wimple, stroll under palm trees, hands clasped on her stomach. Emotion in repose. By the cemetery another nun. Turn. Return. Two thoughts in silent converse like two fishing boats sail side by side in the bay. The sun has set. The boats have docked. Those two nuns turn in to their chapel. From our mosque the muezzin cries this evening's prayer. Our day's done. 


\section{فصل الربيع في الأسكندرية}

هنا، فصل شتائي المهووس أصبح

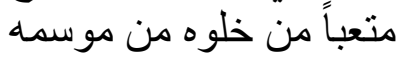

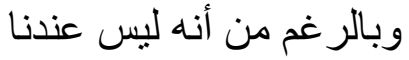

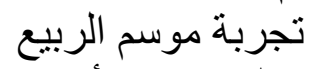

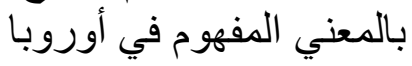

لقد دخلنا في فجوة بين المو اسم ألمريا

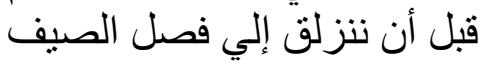

في صورته المشرقة.

ففي هذه الأكسيات و أنا أتناول

المقبلات في بلكونة بيتي

الشمس تغرب ور اء الفر اعنة

و الطيور المهاجرة تتمايل دع نسيم البحر

تستعد للطير ان شمالاً.

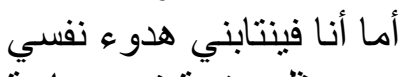

مثل سفينة في زجاجة إنة

تبحر إلى آللامكان.

للأسفل في الدير أثناهد راهبة

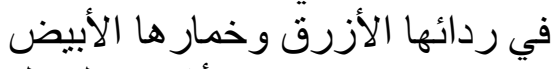

تنتزه تحت أشجار النخيل

أياديها تعانق معدتها.

مشاعر في سكون.

وعند المقابر ، راهبة أخري

تدور، تعودة، تخري،

فكرتين في حديث صنامت نيت

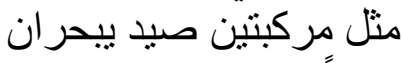

جنباً إلى جنب في الخليج.

غربت الثمس

رست المر اكب الب عنب

هاتان الر اهبتان عادتا

إلى كنيستيهما. 
ومن مسجدنا المؤذن يؤذن

لصلاة العشاء.

إنتهي يومنا. 


\section{AGING SIREN III}

In age she's long in the tooth, on the pension stage.

Of working class, so no family wealth and nothing in the bank, no stocks or shares. Her medical care is common national health.

Her income's from the social security system, she travels by local bus wherever she goes. Her wardrobe's leftovers and charity cast-offs or sale bargains from big basement stores.

For social life she plays the arty clubs but only goes for the first-night reception. There she might meet, among the aging snobs, some lonely gentleman of wealth and station. She's spent her life on the fashionable fringes of the arts, the Schools, the University. She's had to do with, known some famous people in theatre, painting, sculpture, poetry.

Less world-wise then, she took a poet for lover. That we all know is one blind alley. Poets drink your wages, bed your friends, then leave. Yet she survived all that ingenuous folly. Now her old age sings out life's last lament: with whom will she spend her last years of aging? Her children, grown and gone, live far. away with theirs. That's why I hear her love's voice calling. 
إنذار تقدم العمر

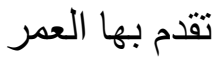

و أصبحت في مرحلة التقاعد

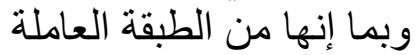

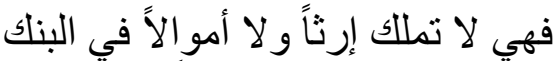

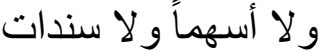

ور عايتها الصحية هي الر عاية الصحية القومية.

عيثها من نظام الضمان الاجتماعي التهاي

وتنقلاتها بالأتوبيس العام الانماع

خز انتها من الصدقات و الإحسان

أو من تخفيضات المخازن الشعبية

من أجل حياتها الإجتماعية

تمثل النو ادي الفنية

ولكنها تحضر فقط الليلة الإحتفالية

ربما تجد في مجمو عة المتذوقين الأنفاء

سيداً وحيداً ذو مال وجناه

لقد قضت حياتها

على هو امش طراز الفنون

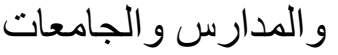

وكان لها صلات ببعض المشاهير

في فنون المسرح و الرسم

و الشعر و النحت.

ولعدم إكتمال نضجها بعد

إتخذت شاعر اً حبيباً لها لها

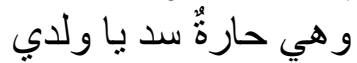

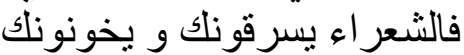

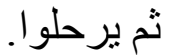

ولكنها صمدت ونجت 
رغم حماقتها وسذاجتها

الآن وهي في أرذل عمر ها:ها

تغني حسر ات أو اخر حياتها

مع من سوف تقضي شيخوختها:

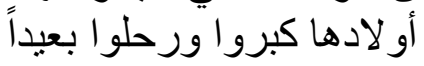

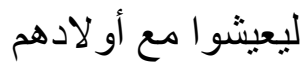

ولذلك أسمع صوتها يناديني ألمهي

وحبها يناجيني 


\section{STRANGER}

He showed up and stayed about a week

at our innocuous kneecapped hotel.

Summer curlicued its stench, matured into Levantine winter.

His room flanked mine.

I observed him daily

through the lattice

from behind my breakfast.

Over coffee he worked letters,

lounging in his loose gallabia.

Gone all day, he never showed

his face till evening when,

against the dirt these buildings

backdrop, he emerged immaculate:

white linen suit, dark silk neckerchief.

Handsomely tall, angularly slouched

in his Victorian wicker chair,

he sipped whisky and water vaguely.

I'd have liked to strike conversation

through some cautious comment and, cracking his calculated reserve, might have shared my isolation with somebody would surely comprehend what I daily try resolve here, alone.

He might have galvanized me. 
غريب

لقد ظهر ومكث مايقرب من أسبوع

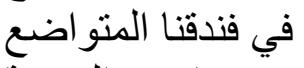

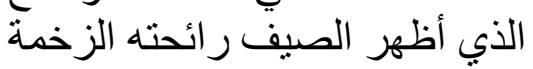

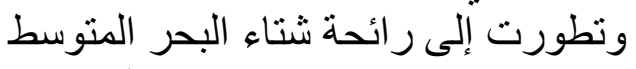

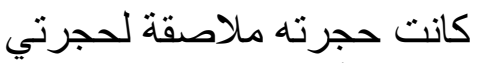

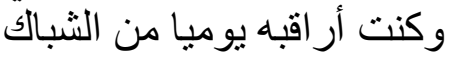

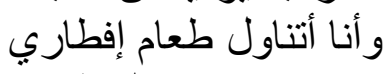

كان يقوم بكتابة بعض الخطابات

و هو يتناول قهوته بعض الخطات

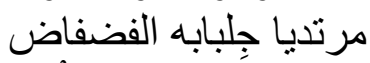

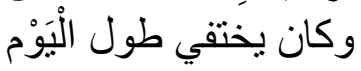

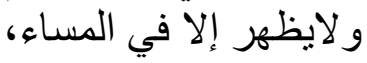

وبالر غم من قذارة المنطقة،

هو في غاية الأناقة

مرتديا بدلة كتان بيضاء غاية الاناه

و منديل حرير أسود

طويل ووسيح

يجلس منثاقلاً

في كرسيه الخيزران

ذو الطراز الفيكتوري

يحتسي الخمر و الماء في غموض ألى أنس

كنت أود أن أتجاذب المع معه

أطر اف الحديث أبث معادي

معلقاً بحذر

ولو اخترقت تحفظه المصطنع

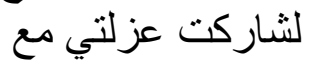

من كان سوف يتفهم

ما أحاول

أن أفهمه أنا أحاونا

هنا بمفردي

كان من الممكن أن يقوي عضدي. 


\section{GOODBYE ALEXANDRIA}

When we met your mature face enthralled me.

Your look, the map of wisdom's labyrinthine invitation we knew could engulf me.

Your midnight eyes' glance shone my naïve love's ruin.

Yet what lay hidden in your silent mind

seduced me into search, in hope to find.

Illi Shusftu. The things that I have seen

show all I need to learn for now, dear friend.

The love envisioned, that slowly might have been consummated as the life of my fond

fantasy, tired to the routinely dull.

We exhausted marriage in our betrothal.

My human penchant for an older woman gave me to you wardrobed in four culture Your face changed with the year's each due season while we indulged our appetites like epicures.

With time, dropped masks, facades revealed your age so that my heart is now turned away from marriage.

Too restless for that end, I must confess your jaded ways no longer raise my fancy, spell out the end of love's exhausted converse. The sirens of new ports sing invitingly. Here I am aging, Alex, dying. My hour has come to sail. Tomorrow I weigh anchor. 
إلى اللقاء يا سكندرية

حين إلتقينا فتنني وجهك الحسن الناضج

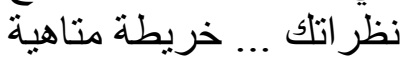

رأيت فيها حكمنك ورشدك خطن

تدوني

كان كلانا يعلم أنها سوف تغدرني

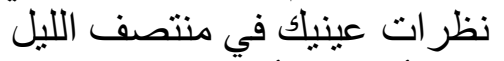

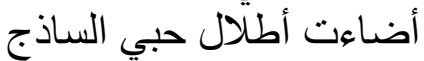

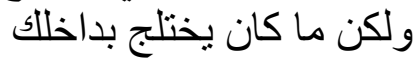

أغو اني أن ابحث فيلك اندان

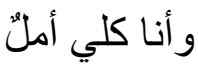

اللي شفتو ا، ما رأيته دلني

على كل ماً أحتاج أن أتعلمه الآن

يا غاليتي

الحب الذي تصورته

و الذي كان ممكن أن يكون الهونه

غذاء الروح لُِيالي المنتيم

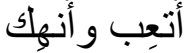

و إنتابه الملل

لقد استنزفنا حبنا في خطبتنا

إن ولعي بالمر أة الناضجة

جعنى آتي اليك مرندياً أربع ثقافات النات

كان وجهأك يتغير أنغات

مع كل فصل من فصول السنة

ونحن نتلذذ بإثباع شهو في اتنا

وبمرور الوقت

سقطت الأقنعة

وكثفت عن عمرك الأك

فجنح قلبي عنك عن 


$$
\begin{aligned}
& \text { وعن الزواج منك } \\
& \text { أعترف أن أساليبك المعتادة } \\
& \text { لم تعد ثتير ولعي الميالي لمعنافي } \\
& \text { وأعترف أني مشتاق لغيرك تُكي } \\
& \text { وأن موانٍ أخري تنتاديني }
\end{aligned}
$$

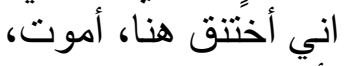

$$
\begin{aligned}
& \text { أنتهي فيكِ يا سكندرية } \\
& \text { لقد حان وقت الرحيل } \\
& \text { غداً أرفع المرساة }
\end{aligned}
$$




\section{CITIES}

Some cities refuse to repeat themselves.

We try to fashion them into cities

of dreams, of memories, or of history;

spun from illusion, peopled by monuments, peopled by statues and paintings in museums that stroll their indoor lives talking business, politics, matters of daily life, love and death.

We describe these cities with pens of imagination or we see them reflected in the caves and cathedrals of God's creation_ phantasmagorias, shadows.

Some cities that we repeat oppose us; turn into lifeless architect's models; become lapidary inscriptions or graffiti, carving in stone, frescos buried under the ash of volcanic time, abandoned temples overgrown by the jungle that's nature and we again return to imaginative reconstruction, repetition.

They rise into reciting or rhetorical voices or into forgotten dances: into crescendo of trumpets and percussion, pounding pianos and orchestration of strings. But the whirling wind of applauding time drowns the flute and the flautist and the dailies and annals of history only print what will be ignored by indifferent history. 
مدن

هناك مدن

ترفض ان تكرر نفسها

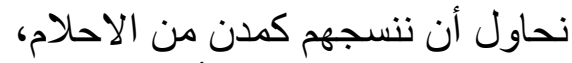

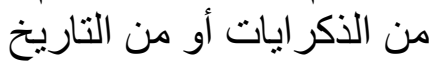

نغز لهم من و هم الخيال

تللك المدن أناسها قطعْ أثرية

أو تماثيل ولوحات في المتاحف

تتجول في عالمها الخاص

تتحدث عن السياسة و الحب في الحباه

و أمور الدنبا و الموت.

تللك المدن نصفها بأقلام من الخيال

أو نرى صور ها محفورة

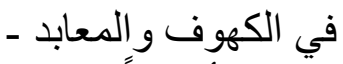

أو هاماً وخيال.

هنالك مدن

ترفض أن تكرر نفسها

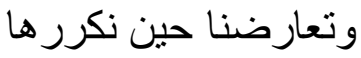

تتحول إلى تماثيل بلا حياة

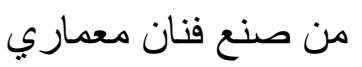

أو إلى كتابات منقوشة على الحجر فئر

أو على الجدران

تتحول الى كتابات جدارية

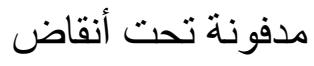

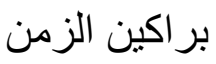

تتحول الى معابد مهجورة

طغت عليها وطمستها الطبيعة

ونظل نحن نحاول

إعادة إحيائها في الخيال.

تلك المدن تصير أصو اتاً جميلة 


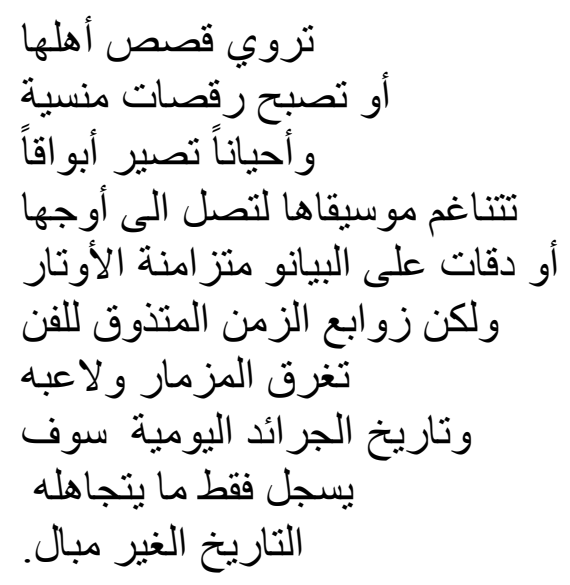




\section{References}

1.Mills, Billy. Desmond O'Grady. A Great Citizen of World Poetry, The Guardian, Aug 2014, https://www.theguardian.com/books/booksblog/2014/a ug/27/desmond-o-grady-world-poetry-billy-mills.

2.O'Grady, Desmond. Sing Me Creation. Dublin: Gallery Books, 1977.

3.O'Grady, Desmond. My Alexandria: Poems and Prose. Alexandria: Bibliotheca Alexandrina, 2006.

4.O’Grady, Desmond. Poetry Festival (Feile Na bealtaine). Limerick, 2008. 